$\xi=$ 不

\title{
Bacteriological and hydrogeochemical investigation of surface water and groundwater in Ikare- Akoko, Nigeria
}

\author{
Ogunribido Thompson Henry Tolulope * \\ Department of Earth Sciences, Adekunle Ajasin University, Akungba - Akoko, Ondo State, Nigeria \\ *Corresponding author E-mail: ogunribido_henry@yahoo.com
}

\begin{abstract}
Ikare Akoko is underlain by the Pre - Cambrian Basement Complex rocks of Southwestern Nigeria and is about 6 kilometers away from Akungba Akoko that host Adekunle Ajasin University. The present study is to assess the quality of natural water for drinking and domestic purposes; perhaps they are susceptible to pollution due to increasing population. Fifteen water samples were collected from both surface water and groundwater during the onset of the dry season for physico - chemical and bacteriological analysis at the Central Research laboratory of Adekunle Ajasin University, Akungba - Akoko. The results indicate low pH, low total dissolved solids and low suspended solids. The concentration of total iron, sodium, calcium, magnesium, potassium, sulphate, bicarbonate and chloride are within the limit of WHO drinking water standard. Lead in most of the samples was below the detection limit but not higher than $0.1 \mathrm{mg} / \mathrm{L}$ and also within the WHO limit of $0.3 \mathrm{mg} / \mathrm{L}$. The bacteriological constituents of the water samples range between $15 \mathrm{and} 30 \mathrm{cfu} / \mathrm{ml}$ indicating bacterial contamination and sources may be due to water contact with cesspits or septic tanks. Therefore water in the study area requires microbial disinfection to upgrade its quality for drinking purposes. Piper's diagram revealed that the hydrogeochemical evolution of water samples in this study area is $\mathrm{Ca}-\mathrm{HCO}_{3}{ }^{-}$, this water have some salinity. Gibb's diagram showed that the concentration of the dissolved chemical constituents were as a result of dissolution of host rock minerals due to water - rock interaction.
\end{abstract}

Keywords: Bacteriological; Contamination; Groundwater; Hydrogeochemical; Surface Water.

\section{Introduction}

The usage of surface water and groundwater for drinking and domestic purposes has increased substantially in the last one decade at Ikare Akoko due to the re-location of former Ondo State University, Ado Ekiti to Akungba -Akoko as Adekunle Ajasin University. Akungba Akoko. The University town is about $6 \mathrm{~km}$ away from Ikare Akoko the study area. Water contamination is prevalent in the last three decade because of the industrial waste usually find it ways back into surface water or groundwater thereby causing health hazard. It is therefore pertinent to analyze for bacteriological and chemical content of this natural waters to determine their suitability for drinking and other uses. Surface water and groundwater may be abundant, but when they are biologically or chemically contaminated, they may not be good for the designed use. The harmful contaminants may include E. coli, coliform or heavy metals such as lead, chromium, arsenic, selenium, barium, mercury or cobalt which are very toxic even at low concentrations. Others are anthropogenic factors such as leachates from land fill site, acid mine drainage, agricultural chemicals, leakage from cesspools, sewage tank and oil spill (Oluyemi et al., 2010, Nton et al., 2007, Obiefuna and Sheriff, 2011, Ahialey et al., 2010).
Various factors are responsible for contamination of natural water which makes them undesirable for drinking and other uses. In the past water supply managers were concerned about the quantity of water supply with no reference to their quality, but due to public health hazard in the recent time quality of water has been greatly considered. Hydrogeochemistry has been used extensively to solve the pressing current and future issues of water scarcity and quality deterioration (Mingming et al. 2011, Anudu et al 2011, Amar and Abderrahmane, 2010, Olarewaju et al. 1997, Elueze et al., 2004).

The purpose of the study was to assess hydrogeochemistry and bacteriological content of the surface water and groundwater in the study area and use it to determine their potability.

\section{Materials and methods}

\subsection{Location and geology of the study area}

Ikare-Akoko, the study areas lies between longitude $5^{0} 45^{\prime} \mathrm{E}$ and $5^{0}$ $50^{\prime}$ East of Greenwich Meridian and latitude $7^{0} 31^{\prime} \mathrm{N}$ and $7^{\circ} 39^{\prime}$ North of Equator (Figure1). 


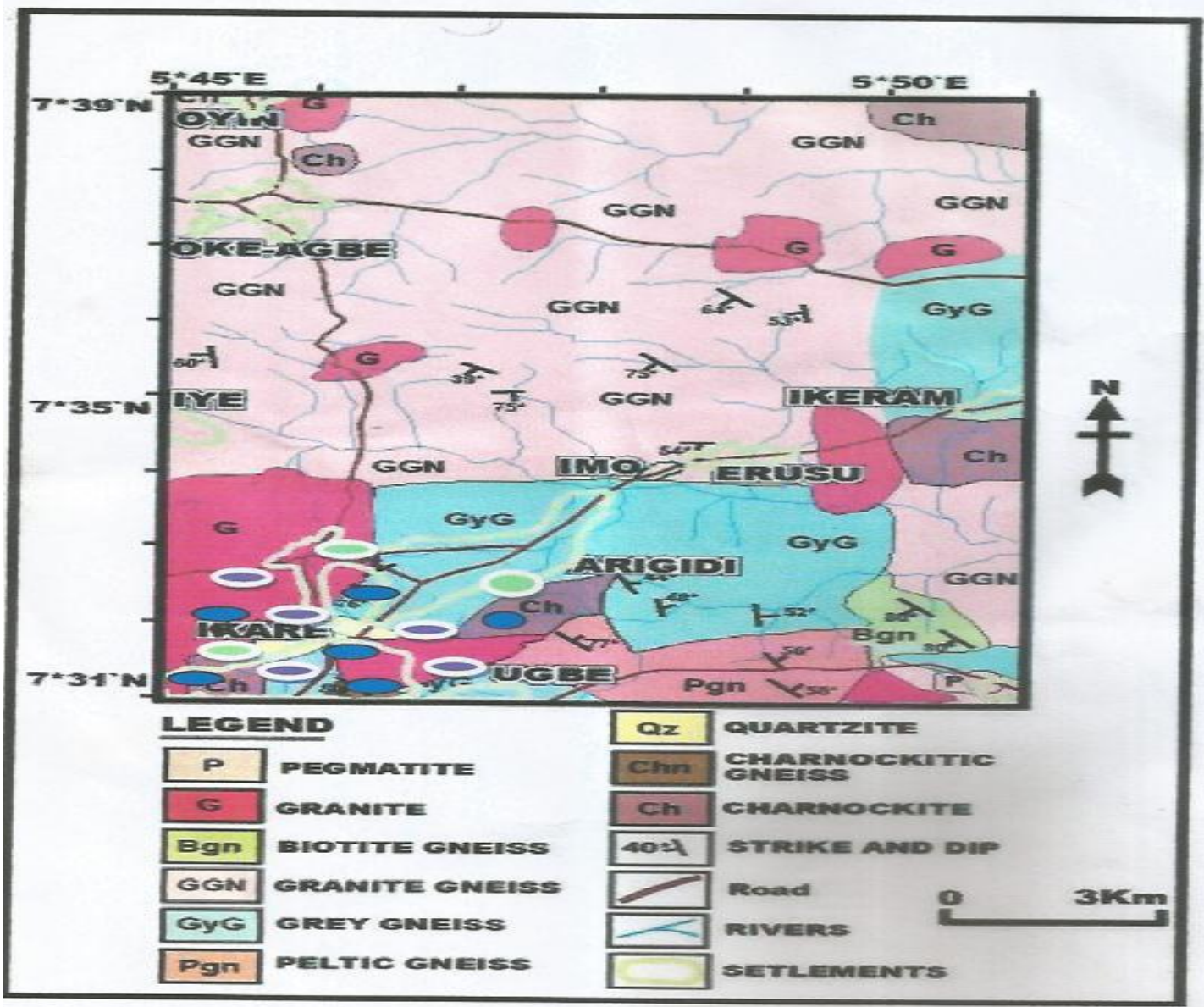

Fig. 1: Geological Map of Ikare - Akoko the Study Area.

The town is underlain by Precambrian crystalline rocks which forms part of the Basement complex of southwestern Nigeria. Four major rock types have been identified in the areas (Rahaman, 1976). These rocks are granite, biotite gneiss, granite gneiss and charnockites. These rocks are massive in nature and outcrop in several places in the study area. These rocks occurred as aquitard except where there was fracturing of rocks or high degree of weathering.

\subsection{Material and methods}

Fifteen water samples were collected which comprises of two surface water and thirteen groundwater that are major sources of drinking water in Ikare metropolis. Water samples were collected in acid washed 2 litres plastic bottles after the bottle was rinsed with water from each sampling point. All containers and equipment were previously soaked in 10 percent $\mathrm{HNO}_{3}$ and rinsed thor- oughly with deionized distilled water before being used for sampling or analyses (Ebrahimpour, 2008). Samples were analyzed at Adekunle Ajasin University Akingba - Akoko. Metals such as lead, calcium, magnesium and iron were analyzed using atomic absorption spectrophotometer, sodium and potassium by flame photometer, other parameter such as bicarbonate, chloride, sulphate, and nitrate concentrations were determined through wet analysis while microbial content were examine using point count Agar. Analytical procedures for physical, chemical and bacteriological parameters were done in accordance with the established standard of APHA 1998.

\section{Results and discussion}

3.1. The result of the chemical properties in the study area is presented in Table 1 and the result of the biological analysis is shown in Table 2

Table 1: Results of the Chemical Analysis of Raw Water Samples

\begin{tabular}{|c|c|c|c|c|c|c|c|c|c|c|c|c|}
\hline S/No & $\begin{array}{l}\text { Sample } \\
\text { code }\end{array}$ & $\begin{array}{l}\mathrm{Ca}^{2+} \\
(\mathrm{mg} / \mathrm{L})\end{array}$ & $\begin{array}{l}\mathrm{Mg}^{2+} \\
(\mathrm{mg} / \mathrm{L})\end{array}$ & $\begin{array}{l}\mathrm{Na}^{2+} \\
(\mathrm{mg} / \mathrm{L})\end{array}$ & $\begin{array}{l}\mathrm{K}^{+} \\
(\mathrm{mg} / \mathrm{L})\end{array}$ & $\begin{array}{l}\mathrm{HCO}_{3}^{-} \\
(\mathrm{mg} / \mathrm{L})\end{array}$ & $\begin{array}{l}\mathrm{SO}_{4}{ }^{2-} \\
(\mathrm{mg} / \mathrm{L})\end{array}$ & $\begin{array}{l}\mathrm{Cl}^{-} \\
(\mathrm{mg} / \mathrm{L})\end{array}$ & $\begin{array}{l}\mathrm{NO}_{3}^{-} \\
(\mathrm{mg} / \mathrm{L})\end{array}$ & $\begin{array}{l}\mathrm{Pb}^{2}+ \\
(\mathrm{mg} / \mathrm{L})\end{array}$ & $\begin{array}{l}\mathrm{Fe}^{2+} \\
(\mathrm{mg} / \mathrm{L})\end{array}$ & $\begin{array}{l}\text { SS } \\
(\mathrm{mg} / \mathrm{L})\end{array}$ \\
\hline 1 & SW1 & 54 & 31 & 16 & 7 & 237 & 1.20 & 92 & 0.05 & N.D & 0.01 & 0.72 \\
\hline 2 & GW1 & 60 & 33 & 24 & 12 & 97 & 1.25 & 187 & 0.95 & 0.01 & 0.10 & 0.56 \\
\hline 3 & GW2 & 66 & 33 & 26 & 8 & 170 & 0.95 & 187 & 0.22 & N.D & 0.02 & 0.25 \\
\hline 4 & GW3 & 43 & 9 & 28 & 16 & 359 & 2.27 & 258 & 1.10 & 0.01 & 0.10 & 1.20 \\
\hline 5 & GW4 & 25 & 40 & 16 & 5 & 79 & 0.16 & 67 & 0.35 & N.D & 0.12 & 0.55 \\
\hline 6 & GW5 & 49 & 19 & 23 & 10 & 152 & 1.00 & 148 & 0.91 & 0.01 & 0.10 & 0.52 \\
\hline 7 & GW6 & 30 & 62 & 12 & 4 & 140 & 0.27 & 31 & 0.27 & N.D & 0.32 & 0.63 \\
\hline 9 & GW8 & 16 & 37 & 19 & 6 & 73 & 0.52 & 49 & 0.21 & N.D & 0.21 & 0.38 \\
\hline 10 & GW9 & 30 & 40 & 12 & 2 & 128 & 0.55 & 60 & 0.25 & N.D & 0.01 & 0.27 \\
\hline 11 & GW10 & 50 & 2 & 27 & 10 & 73 & 0.87 & 127 & 0.15 & N.D & 0.02 & 0.56 \\
\hline 12 & SW2 & 71 & 45 & 22 & 13 & 109 & 0.80 & 60 & 0.13 & 0.01 & 1.00 & 0.45 \\
\hline 13 & GW11 & 22 & 59 & 10 & 3 & 61 & 0.45 & 39 & 0.19 & N.D & 0.07 & 0.33 \\
\hline 14 & GW12 & 17 & 99 & 8 & 3 & 61 & 0.32 & 28 & 0.11 & N.D & 0.10 & 0.51 \\
\hline 15 & GW13 & 26 & 13 & 6 & 2 & 48 & 0.43 & 49 & 0.17 & N.D & 0.11 & 0.35 \\
\hline
\end{tabular}


Table 2: Results of the Physical and Biological Analyses of Raw Water Samples

\begin{tabular}{|c|c|c|c|c|c|c|c|c|}
\hline S/No & Sample Code & E - coli & $\begin{array}{l}\text { Total dissolved } \\
\text { solids }\end{array}$ & $\mathrm{EC} \mu \mathrm{S} / \mathrm{cm}$ & Temp ${ }^{\circ} \mathrm{C}$ & Total Hardness & $\mathrm{pH}$ & $\begin{array}{l}\text { Turbidity } \\
\text { NTU }\end{array}$ \\
\hline 1 & SW1 & 2 & 146.4 & 320 & 25 & 221 & 5.6 & 0.85 \\
\hline 2 & GW1 & 0 & 167.9 & 420 & 25.6 & 246 & 6.7 & 1.25 \\
\hline 3 & GW2 & 0 & 129.9 & 325 & 25 & 264 & 5.9 & 0.81 \\
\hline 4 & GW3 & 0 & 311.4 & 560 & 25 & 162 & 6.9 & 0.96 \\
\hline 5 & GW4 & 0 & 172.3 & 420 & 25 & 128 & 6.5 & 0.46 \\
\hline 6 & GW5 & 0 & 472.6 & 320 & 25 & 193 & 5.9 & 0.96 \\
\hline 7 & GW6 & 0 & 134.3 & 310 & 25 & 167 & 6.5 & 0.43 \\
\hline 8 & GW7 & 0 & 196.5 & 470 & 25 & 296 & 6.7 & 0.75 \\
\hline 9 & GW8 & 0 & 50.2 & 430 & 25 & 96 & 6.2 & 0.29 \\
\hline 10 & GW9 & 0 & 82.6 & 455 & 25 & 145 & 7.0 & 0.33 \\
\hline 11 & GW10 & 0 & 51.8 & 255 & 25 & 180 & 6.5 & 0.45 \\
\hline 12 & SW2 & 1 & 148.4 & 440 & 25.5 & 294 & 6.5 & 0.43 \\
\hline 13 & GW11 & 0 & 167.9 & 469 & 25 & 137 & 7.0 & 0.25 \\
\hline 14 & GW12 & 0 & 311.8 & 350 & 25 & 161 & 6.1 & 0.25 \\
\hline 15 & GW13 & 0 & 129.9 & 360 & 25 & 104 & 6.9 & 0.25 \\
\hline
\end{tabular}

\subsection{Piper's diagram}

Piper's diagram can be used to determine hydrogeochemical facies of natural waters (Freeze and Cherry, 1979). Piper's diagram are drawn by plotting the proportion of major cations on one triangular diagram, the proportions of the major anions on the other triangular diagram and combining the information from the two trian- gles on a quadrilateral (Hussain et al., 2008) The major cations and anions were plotted on the piper's diagrams to delineate the water types present in the study area (Figure 2). The result of the water plots in Ikare indicated bicarbonate water type, the bicarbonate facies encountered was $\mathrm{Ca}-\left(\mathrm{HCO}_{3}\right)^{2}$. This facies represent fresh recharge (Offodile, 2002, Olobaniyi et al., 2007). The piper's diagram

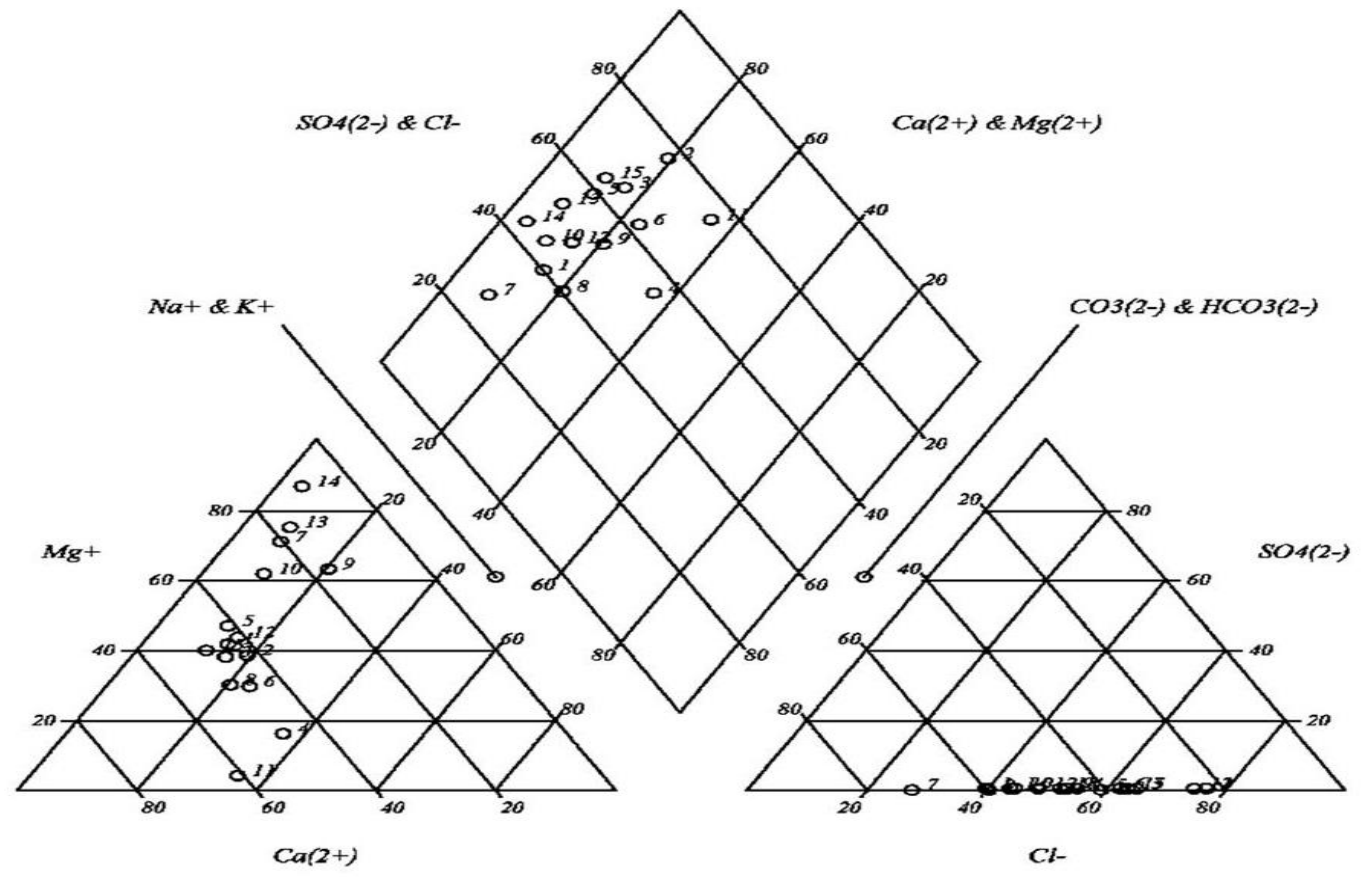

Fig. 2: Piper's Diagram of Raw Groundwater Samples.

clearly shows that cation exchange has increased the calcium $\left(\mathrm{Ca}^{2+}\right)$ concentration at the expense of Sodium $\left(\mathrm{Na}^{+}\right)$and magnesium $\left(\mathrm{Mg}^{2+)}\right.$ concentrations. Ikare is underlain by gneissic rocks that have weathered to clayey soil. Clay minerals have high cation exchange capacities leading to high ion exchange capacity in the natural waters in the study area (Hem, 1985).

\subsection{Gibbs diagram}

Gibbs (1970) designed a diagram to interpret the relationship between the chemical component of waters and their respective aquifer lithologies. The Gibbs diagram has three distinct fields, namely precipitation, evaporation and rock dominance areas. For this study, the Gibbs ratio $\mathrm{I}, \mathrm{Na}^{+} /\left(\mathrm{Na}^{+}+\mathrm{Ca}^{2+}\right)$ for cations of water samples were plotted separately against the respective values of the total dissolved solids (TDS). The purpose was to understand the processes and mechanism responsible for the modification of the groundwater chemistry (Ogunribido, 2014). According to ratio I for groundwater in the study area, the rock types and their weathered products have significantly contributed to the modification of the water chemistry. Gibbs plots indicate rock dominance of greater percentage and the rest as precipitation (Figure 3 ). This suggests that the dissolved constituents of the groundwater could be attributed to chemical weathering of the rock forming minerals and atmospheric precipitation. Evaporation concentrates the remaining water, which lead to precipitation and deposition of evaporate that was eventually leached into the saturated zone. 


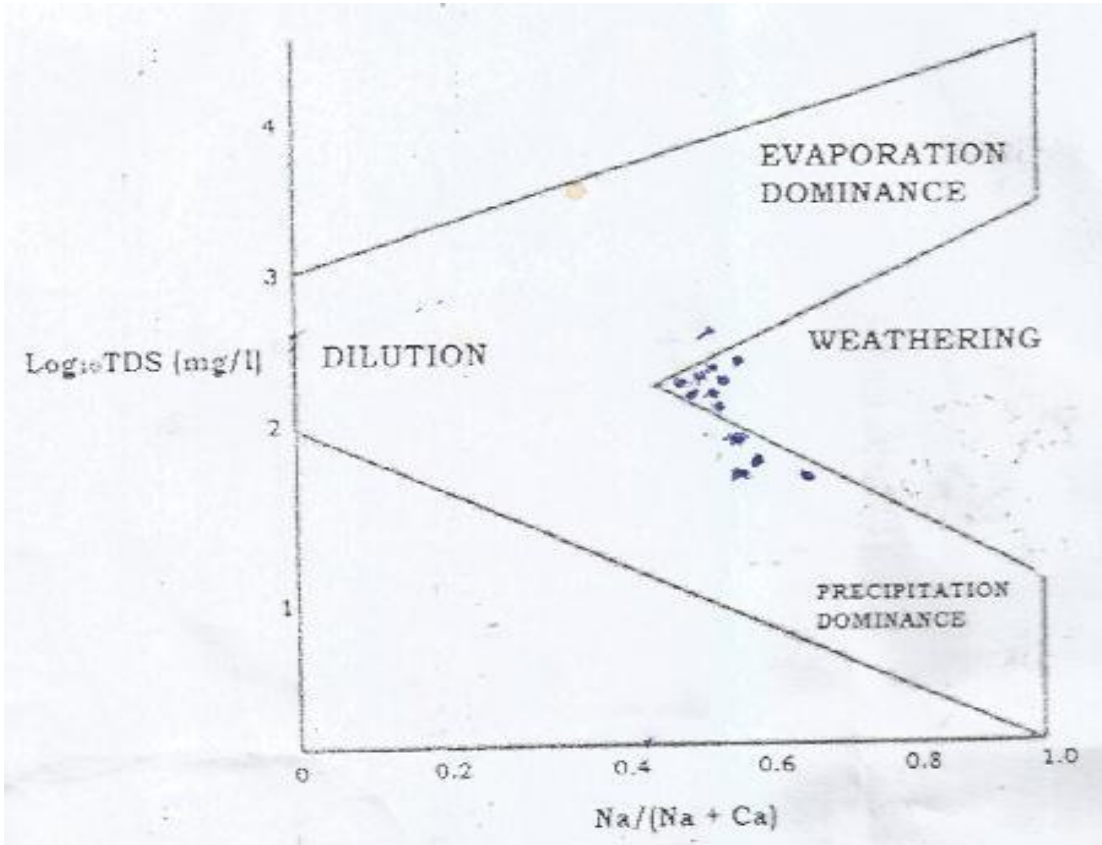

Fig. 3: Gibbs Diagram for Raw Groundwater Samples.

\subsection{Bar charts for raw water samples}

The bar charts of mean concentrations for major ions for both surface water and groundwater samples in the study area (Figures 4 and 5) showed that bicarbonate ion has the highest mean con- centration and sulphate ion has the lowest mean concentration. Calcium ion has the highest mean concentration among the cations, showing high ion exchange capacity among calcium, magnesium and sodium.

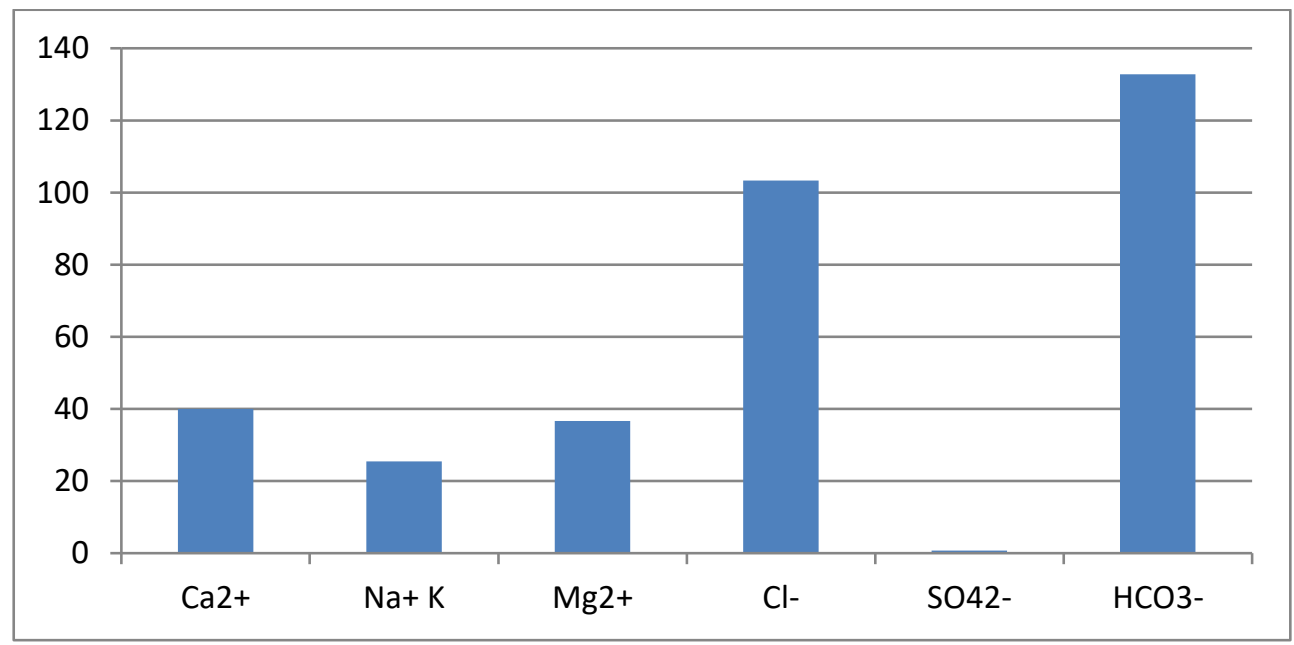

Fig. 4: Bar Charts of Mean Major Ions in the Groundwater Samples.

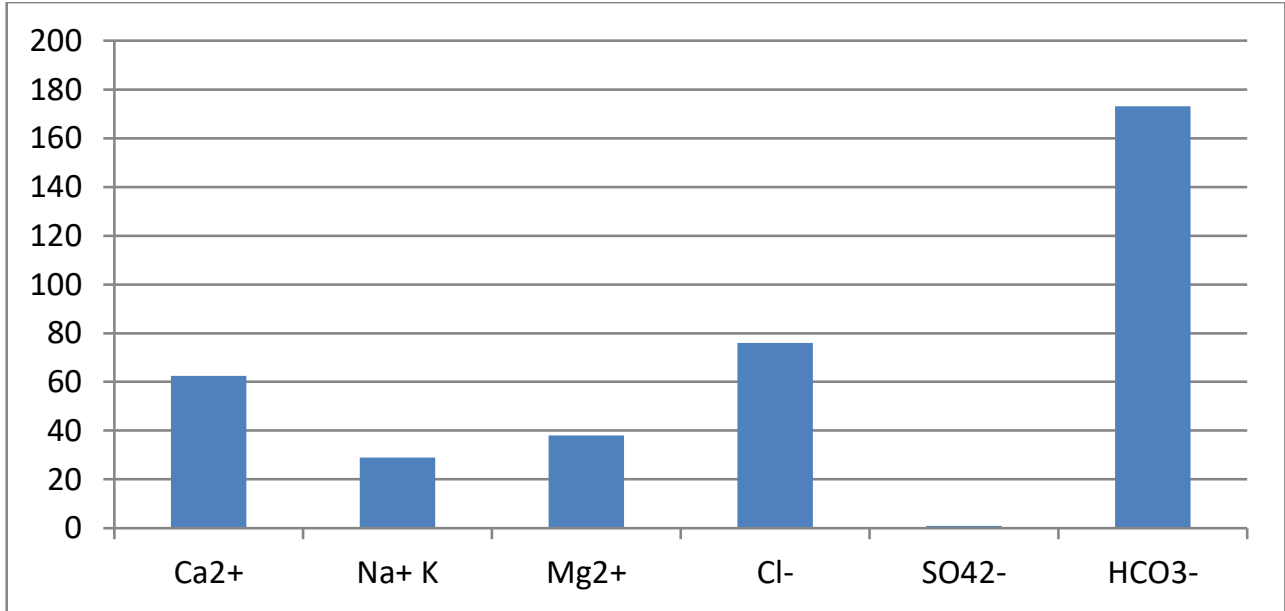

Fig. 5: Bar Charts of Mean Major Ions in the Surface Water Samples. 


\subsection{Pie charts}

Pie charts (Figures 6 and 7) were used to plot the mean concentration ratio of major ions for surface water and groundwater sam- ples. The purpose is to compare concentration ratios of the major ions present in the raw water samples in the study area.

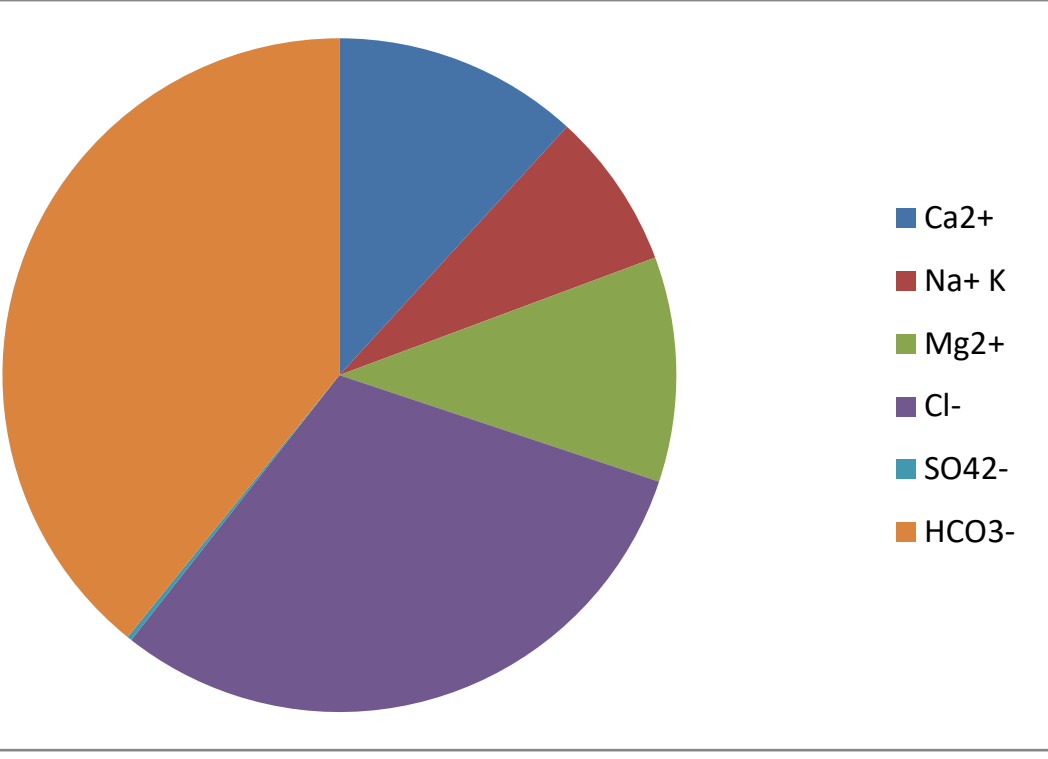

Fig. 6: Pie Chart of Mean Concentration of Major Ions in Groundwater Samples.

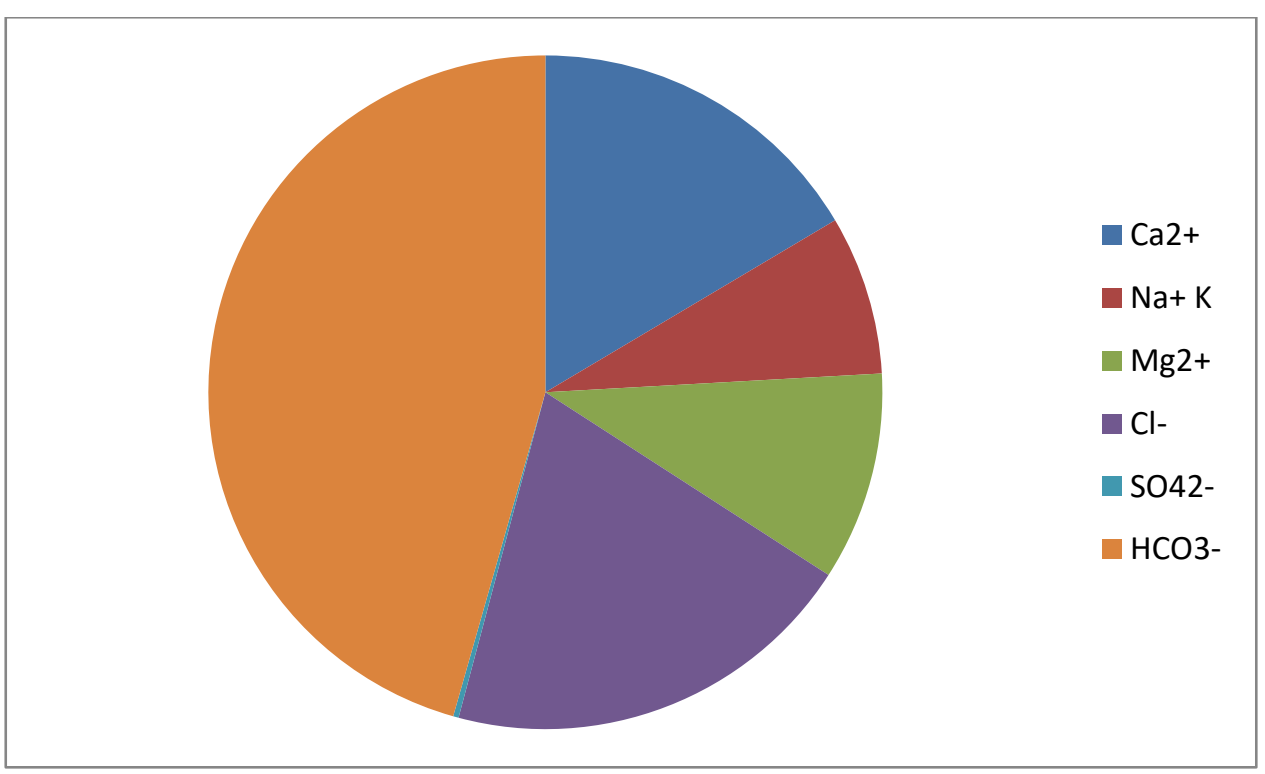

Fig. 7: Pie Chart of Mean Concentration of Major Ions in Surface Water Samples.

\subsection{Line graphs}

Line graphs (Figures 8 and 9) of mean concentration of major ions shows similar trend with the bar charts for both surface water and groundwater in the study area. Sulphate ion has the lowest mean concentration of all the major ions. All the major ions concentration still occurred within the drinking water standard of WHO (2011). 


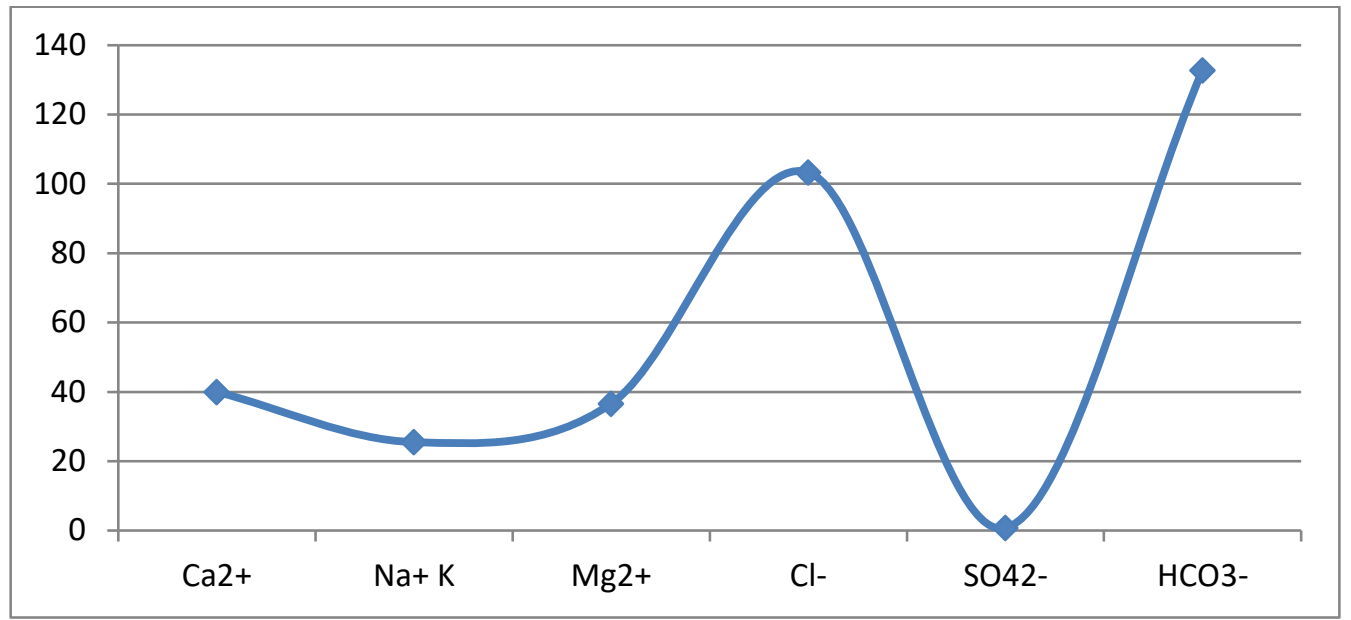

Fig. 8: Line Graph of Mean Concentration of Major Ions in Groundwater Samples.

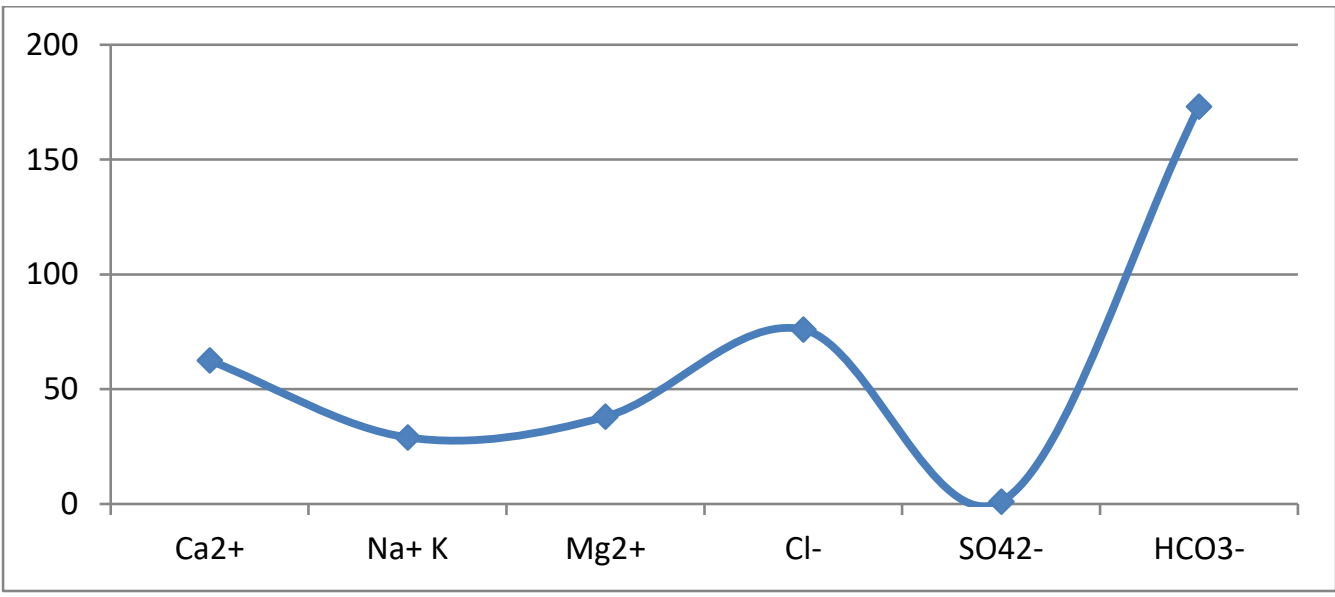

Fig. 9: Line Graph of Mean Concentration of Major Ions in Surface Water Samples.

\subsection{Hydrogeochemical}

Hydrochemical results show that the groundwater has $\mathrm{pH}$ range of $5.9-7.0$ and thus is moderately acidic to neutral and for surface water; it ranges between 5.6 and 6.0, which is moderately acidic. The hardness is $<60 \mathrm{mg} / \mathrm{l}$, and thus is classified as soft water. Fetter (1990) classified water with TDS values $<1,000 \mathrm{mg} / \mathrm{l}$ as fresh The groundwater in Ikare has a TDS range of $50.2-472.6 \mathrm{mg} / \mathrm{L}$ and for the surface water was between 146.4 and $148.4 \mathrm{mg} / \mathrm{L}$, thus, water samples from the study area can be regarded as fresh water. Sulphate reduction caused by anaerobic bacteria may have contributed to the elevation of $\mathrm{HCO}_{3}{ }^{-}$, partly at the expense of $\mathrm{SO}_{4}{ }^{2-}$, whose concentration in the groundwater is minute relative to $\mathrm{HCO}_{3}{ }^{-}$. This also indicates a reducing environment for the groundwater and surface water in Ikare Akoko.

Although heavy metals result from human activities (industrial and agricultural) and radioactivity (Matthes and Miller, 1994), the elevated concentrations of iron, manganese and lead cannot be attributed to any of these sources because Ikare is neither an industrial nor a heavy agricultural area. These metals may have originated from natural process(s).

The maximum permissible limit of concentration of nitrate by World Health Organization is $10 \mathrm{mg} / \mathrm{L}$. In the study area, nitrate concentrations range between 0.05 and $0.95 \mathrm{mg} / \mathrm{L}$, this shows that the concentration of nitrate is less than the WHO limits and there is no nitrate enrichment in surface water and groundwater samples. The turbidity in the water samples ranged between 0.25 and 1.25 NTU which fall within the permissible level of WHO 1998 drinking standard for household use. Electrical conductivity ranged between 255 and $560 \mu \mathrm{S} / \mathrm{cm}$ in the water samples thus indicating less mineralized water.
The concentrations of $\mathrm{Na}^{2+}, \mathrm{Mg}^{2+}, \mathrm{Ca}^{2+}, \mathrm{K}^{+}, \mathrm{HCO}_{3}{ }^{-}, \mathrm{SO}_{4}{ }^{2-}$ and $\mathrm{Cl}^{-}$ in the water samples are within the recommended limits of WHO drinking water standard.

The occurrence of $\mathrm{E}$ - coli bacteria which range between 0 and 2 $\mathrm{cfu} / 100 \mathrm{ml}$ is higher than $0 \mathrm{cfu} / 100 \mathrm{ml}$ as WHO guideline for potability and this suggest that the water sources have been contaminated with pathogenic microorganism of faecal origin (Table 2). The possible sources of the coliform might be due to indiscriminate defecation or contaminated run - offs from broken septic tanks gained entrance into their water sources. The chemistry of the springs and groundwater in the study area is generally controlled by the water - rock interaction and to a lesser extent by the anthropogenic factors, since there no anomaly that can be traced to ores enrichment or effluent water discharge.

\section{Conclusion}

Based on the microbial and hydrogeochemical studies of surface water and groundwater in Ikare Akoko, Surface water in the study are bacteriological contaminated, though the dissolved chemical constituents in the surface water and groundwater samples were within the WHO drinking water standard. It is therefore recommended that there should be microbial disinfection to remove $\mathrm{E}$ coli bacteria to improve the quality of the surface water before consumption.

\section{References}

[1] Ahialey, E.K., Serfor - Armah, Y and Rortatsi, B.K. Hydro chemical Analysis of Groundwater in Lower Pra Basin of Ghana, Journal of Water Resource and Protection, 2010. 2: 864 - 871 . https://doi.org/10.4236/jwarp.2010.210103. 
[2] Ammar, T., and Abderrahmane, B. Hydrochemical Analysis and Assessment of Surface Water Quality in Koudiat Medouar Reservoir, Algeria, European Journal of Scientific Research. 2010, 41: $273-285$.

[3] Anudu, G.K, Obrike, S.E, Onuba, L.N and Ikpokonte. Hydrochemical analysis and evaluation of water quality in Angwan Jeba and its envions, Nasarawa state, Northern Nigeria, Research Journal of Applied Sciences, 2011, 6(2): $128 \quad-\quad 135$ https://doi.org/10.3923/rjasci.2011.128.135.

[4] APHA .Standard methods for the examination of water and wastewater. 1998 APHA, New York.

[5] Ebrahimpour M.M. Heavy metal concentrations in water and sediments in Tasik Chini, a fresh water lake, Malaysia, Environmemtal monitoring and assessment, 2008, 14(1-3), $297-307$.

[6] Elueze, A.A., Omidiran, J.O. and Nton, M.E. Hydrogeochemical Investigation of Surface Water and Groundwater around Ibokun, Ilesha Areas, Southwestern Nigeria, Journal of Mining and Geology. 2004, 40 (1): 57 - 64. https://doi.org/10.4314/jmg.v40i1.18809.

[7] Fetter, C.W., 1990. Applied hydrogeology. CBS Publishers and Distributors, New Delhi, India, 567p.

[8] Freeze, R.A. and Cherry, J.A., 1979. Groundwater. Prentice-Hall Press, Austin, Texas, 567p.

[9] Gibbs, R.J., 1970. Mechanisms controlling world water chemistry. Science, $\quad 170 \quad$ (3962), pp.1088-1090. https://doi.org/10.1126/science.170.3962.1088.

[10] Hem, J.D. 1985. Study and interpretation of the chemical characteristics of natural water. United States Geological survey water supply paper $2254,244 \mathrm{p}$.

[11] Hounslow, A.W., 1995. Water quality data: Analysis and Interpretation. CRS Press, Inc. Lewis.

[12] Publishers, 397p.Igboekwe, M.U., Okwueze, E.E. and Okereke C.S., 2006. Delineation of potential aquifer zones from geoelectric soundings in Kwaibo river watershed, southeastern Nigeria. Journal of engineering and applied sciences, vol.4, pp.410-421.

[13] Hussain, M., Ahmed, S.M., and Abderrahman, W. (2008): Cluster Analysis and Quality Assessment of Logged Water at an Irrigation Project, Eastern Saudi Arabia. Journal of Environmental Management, 86, 297 - 307. https://doi.org/10.1016/j.jenvman.2006.12.007.

[14] Matthes, G., and Miller, J.C., 1994. Chemical and biological contaminants and their surface behaviour. In Jerosla, V. and Alexander, Z. (eds.), Guidebook on mapping groundwater vulnerability, vol. 16, pp. 11-17.

[15] Mingming, J, Wei, T. Z, Yuan,Y, Julia, E.B, Min , X, Chen , Y, Lina, $\mathrm{S}$ and Mingzhong, $\mathrm{L}$.

[16] Water geochemical characteristic variation in and around a karst dominated Natural reserve area, Southwestern China, Environ. Earth Sciences, 2011, 64: $1051 \quad-\quad 1058$. https://doi.org/10.1007/s12665-011-0923-1.

[17] Nton , M.E, Adejumo, S.A, and Elueze, A.A. Hydrogeochemical assessment of surface Water and groundwater quality in Agbowo Orogun area of Ibadan, SW Nigeria, Global Journal Geological Science, 2007, 5, no. 1 \& 2: $13-23$.

[18] Obiefuna, G.I and Sheriff, A. Assessment of shallow groundwater quality of Pindiga Gombe Area, Yola Area, NE, Nigeria for irrigation and domestic purposes, Research Journal of environmental and earth sciences, 2011, 3(2): $131-141$.

[19] Offodile 2002. Groudwater study and development in Nigeria, 2nd edition, Mecon publishers, 453p.

[20] Ogunribido, T.H.T 2014. Hydrogeochemical and contaminant studies of Surface water and groundwater in Agbabu area, SW Nigeria, Unpublished $\mathrm{PhD}$ thesis, OOU, 210p.

[21] Olarewaju, V.O., Olorunfemi, M.O. and Alade, O. Chemical characteristics of groundwater from some parts of the Basement complex of central Nigeria, Journal of Mining and Geology, 1997. 33. No 2: $135-139$.

[22] Olobaniyi S.B., Ogala J.E and Nfor N.B. Hydrogeochemical and bacteriological Investigation of groundwater in Agbor Area, Southern Nigeria, Journal of Mining and Geology, 2007, 43(1) : $79-89$. https://doi.org/10.4314/jmg.v43i1.18867.

[23] Oluyemi, E.A, Adekunle, A.S, Adenuga, A.A and Makinde, W.O Physico-chemical.

[24] Properties and heavy metal content of water sources in Ife North Local Government Area of Osun State, Nigeria. Afrcan Journal of Environmental science and technology 2010, 4(10): $691-697$.

[25] Rahaman, M.A. Review of the basement complex geology of Southwestern Nigeria, in C. A Kogbe (ed) Geology of Nigeria, Elizabethan publishing co. Lagos, 1976: 41 - 55.

[26] WHO, Guidelines for drinking water quality, Geneva. 1998

[27] WHO, Guidelines for drinking water quality, Geneva. 2011. 